\title{
Penerapan Aspek Keberfungsian Sosial Levin Sebagai Instrumen Asesmen di Panti Lansia Bojongbata Pemalang
}

\section{Wina Nurdini Kodaruddin ${ }^{1}$, Sri Sulastri ${ }^{2}$, Hery Wibowo ${ }^{3}$}

winanurdini@gmail.com, sri.sulastri@unpad.ac.id, hery.wibowo@unpad.ac.id

${ }^{1}$ Pasca Sarjana Ilmu Kesejahteraan Sosial Universitas Padjadjaran

${ }^{2}$ Program Studi Kesejahteraan Sosial Universitas Padjadjaran

3 Program studi Sosiologi Universitas Padjadjaran

DOI https://doi.org/10.22219/sospol.v6i2.12981

\begin{abstract}
Based on Central Java Governor Regulation No. 31/2018, the Bojongbata Nursing

Home used to provide social services for the elderly. Unfortunately, Bojongbata Nursing Home does not have a special instrument for assessing the elderly's social function. The social function assessment usually used maps of social network and list of questions related to the elderly social relationships. However, this instrument has not been able to thoroughly explore the conditions, problems and needs of the elderly. In fact, an in-depth assessment of social functioning affects the determination of appropriate interventions and helps social workers analyze the conditions and service needs of the elderly. This study aims to identify the social functioning of the elderly through the aspects of Social Resources, Social Activities, Social Networking, Social Support, and Social Role and Role Functioning. This study analyzed several elderly informants with the aim of identifying their social functioning based on potential and non-potential groups. This is done to find differences in the conditions and needs of the two. The results of this study indicate that Levin assessment theory can describe the social functioning of the elderly. There is a relationship between aspects in realizing the better social functioning of the elderly. Elderly who can make good use of social resources and have adequate social activities have a wider and stronger social network. This social network can provide the social support needed by the elderly in carrying out their social roles properly.
\end{abstract}

\footnotetext{
Abstrak

Berdasarkan Peraturan Gubernur Jawa Tengah Nomor 31 Tahun 2018, Panti Jompo Bojongbata digunakan untuk memberikan pelayanan sosial kepada lansia. Sayangnya Panti Jompo Bojongbata belum memiliki instrumen khusus untuk menilai fungsi sosial lansia. Penilaian fungsi sosial biasanya menggunakan peta jejaring sosial dan daftar pertanyaan yang berkaitan dengan hubungan sosial lansia. Akan tetapi, instrumen ini belum mampu menggali secara menyeluruh kondisi, permasalahan dan kebutuhan lansia. Faktanya, penilaian mendalam tentang fungsi sosial mempengaruhi penentuan intervensi yang tepat dan membantu pekerja sosial menganalisis kondisi dan kebutuhan layanan lansia. Penelitian ini bertujuan untuk mengetahui fungsi sosial lansia melalui aspek Sumber Daya Sosial, Kegiatan Sosial, Jejaring Sosial, Dukungan Sosial, dan Fungsi Peran dan Peran Sosial. Penelitian ini menganalisis beberapa informan lansia dengan tujuan untuk mengidentifikasi fungsi sosial mereka berdasarkan kelompok potensial dan non potensial. Hal ini dilakukan untuk mengetahui perbedaan kondisi dan kebutuhan keduanya. Hasil penelitian ini menunjukkan bahwa teori asesmen Levin dapat menggambarkan fungsi sosial lansia. Ada keterkaitan antar aspek dalam mewujudkan fungsi sosial lansia yang lebih baik. Lansia yang mampu memanfaatkan sumber daya sosial dengan baik dan memiliki kegiatan sosial yang memadai memiliki jaringan sosial yang lebih luas dan kuat. Jejaring sosial ini dapat memberikan dukungan sosial yang dibutuhkan lansia dalam menjalankan peran sosialnya dengan baik.
}

\section{Keywords:}

Assessment Levin, Elderly,

Nursing Home, Social

Function, Social Worker

\section{Article History}

Received July 21, 2020

Revised July 29, 2020

Accepted September 14, 2020

Published October 19, 2020

\section{Corresponding Author}

Wina Nurdini

Kodaruddin. PPSLU

Bojongbata Pemalang

Jl. Dr. Cipto

Mangunkusumo No. 4

Pemalang Jawa Tengah. 52319 


\section{Pendahuluan}

Berdasarkan pernyataan pemerintah melalui Bappenas bersama Badan Pusat Statistik (BPS) dan United Nations Population Fund (UNFPA), pada tahun 2045 penduduk Indonesia diperkirakan mencapai 318,9 juta jiwa (dengan asumsi Total Fertility Rate (TFR) bertahan di angka 2,1). Jumlah penduduk lanjut usia mengalami peningkatan 19,8 persen sehingga sekitar seperlima penduduk Indonesia di tahun tersebut merupakan lansia (Seftiani, 2018). Oleh sebab itu, bertambahnya jumlah lanjut usia di Indonesia setiap tahunnya perlu dikelola dengan baik. Peringatan Hari Lanjut Usia Nasional yang berlangsung setiap 29 Mei mengamanatkan misi lanjut usia untuk dapat hidup dengan sehat, aktif, dan produktif (Kemenkes RI, 2016). Seperti yang kita ketahui bersama, orang yang berusia lanjut rentan mengalami berbagai tekanan psikologis maupun masalah sosial lainnya. Penting bagi keluarga dan lingkungan untuk memahami mendukung kesehatan fisik maupun psikologis usia lanjut ((Azizah \& Hartanti, 2016; Nailufar, 2019; Seftiani, 2018; Wicaksono, 2017).

Berdasarkan Permensos nomor 19 Tahun 2012, pelayanan sosial bagi lanjut usia dapat dilakukan di luar panti maupun di dalam Panti. Pelayanan sosial bagi lanjut usia di dalam lingkup Panti merupakan pilihan akhir, karena diutamakan perawatan terbaik ada pada keluarga atau kerabatnya. Sebagai penjabaran dan pelaksanaan dari Pergub Jawa Tengah No. 31 Tahun 2018, Panti Pelayanan Sosial Lanjut Usia Bojongbata Pemalang merupakan salah satu Unit Pelaksana Teknis dari Dinas Sosial Provinsi Jawa Tengah menjalankan fungsi pelayanan sosial bagi lanjut usia dengan salahsatu tujuannya meningkatkan harkat dan martabat serta kualitas hidup lanjut usia. Dengan demikian, panti lanjut usia/ panti jompo berperan dalam memfasilitasi intervensi psikososial oleh pekerja sosial untuk meningkatkan keberfungsian sosial lanjut usia (Syamsuddin, Santi, \& Alimuddin, 2018).

Berkenaan dengan studi kasus pada penelitian ini, Panti Lanjut Usia Bojongbata Pemalang belum memiliki instrumen khusus untuk asesmen kondisi keberfungsian sosial lanjut usia. Pelaksanaan asesmen keberfungsian sosial saat ini menggunakan alat bantu asesmen peta jaringan sosial dan daftar pertanyaan berkaitan dengan hubungan sosial lansia saja. Namun masih terdapat kekurangan karena belum dapat menggali kondisi, masalah, dan kebutuhan lansia secara menyeluruh. Padahal penilaian keberfungsian sosial yang mendalam sangatlah penting dilakukan, karena akan mempengaruhi penentuan intervensi yang tepat serta membantu pekerja sosial dalam mengetahui kondisi serta menilai kebutuhan layanan dari lanjut usia yang sesungguhnya.

Sejumlah penelitian tentang keberfungsian pada lanjut usia telah dilakukan diantaranya kajian keberfungsian sosial lansia yang mengalami skizofrenia (Meesters et.al, 2010); perbandingan pengukuran keberfungsian sosial pada 3 kelompok lansia berbeda yakni kelompok lansia yang tidak memiliki morbiditas psikiatrik, kelompok lansia yang mengalami depresi dan kelompok lansia dengan skizofrenia (Graham, et.al, 2002); problem penghambat keberfungsian sosial lanjut usia yakni kesibukan lansia, sumber keuangan, kegiatan lansia, pandangan lansia terhadap panti, hubungan lansia dengan orang lain, hubungan lansia dengan keluarga, ketergantungan lansia, hobi lansia dan kondisi fisiknya (Juriatun, 2015); aspek peranan pekerja sosial dalam meningkatkan keberfungsian sosial yakni sebagai broker yang menghubungkan klien dengan sistem sumber yang dibutuhkan dalam rangka meningkatkan keberfungsian sosialnya (Muthia, et.al, 2016); perspektif kekuatan dan keberfungsian sosial lanjut usia di panti yang pelaksanaanya dengan keterlibatan lansia dalam bidang kebudayan, pengetahuan dan 
keterampilan serta spiritual dan nilai-nilai moral kehidupan (Syamsuddin, Santi, \& Alimuddin, 2018).; serta upaya peningkatan keberfungsian lansia melalui program pelatihan kembali dalam bentuk kognitif retraining, motor retraining dan emosional retraining. (Syamsuddin, 2018).

Masing - masing penelitian yang telah ada memberikan penekanan yang berbeda tentang pekerjaan sosial, namun belum ada yang secara khusus membahas tentang instrumen untuk asesmen keberfungsian sosial. Berdasarkan penjelasan tersebut diatas, penelitian ini penting untuk melengkapi asesmen pada lanjut usia di Panti juga hasil pendalaman kondisi keberfungsian sosial ini dapat mempengaruhi berbagai aspek kehidupan bagi lansia seperti kesehatan, aktivitas, dan terutama dalam menentukan kebutuhan layanan bagi lanjut usia yang tinggal di Panti.

\section{Keberfungsian Sosial Usia Lanjut}

Menurut DuBois \& Milley (2011), keberfungsian sosial mencakup upaya untuk memenuhi kebutuhan dasar, membangun hubungan positif, dan menekankan pertumbuhan serta penyesuaian pribadi. Konsepsi ini mengedepankan bahwa manusia adalah subjek dari seluruh proses dan aktivitas kehidupannya. Manusia dianggap memiliki kemampuan dan potensi yang dapat dikembangkan dalam proses pertolongan. Masalah keberfungsian sosial dapat terjadi pada setiap tahapan kehidupan dan setiap orang, karena setiap manusia memiliki keunikan individu serta interaksi yang berbeda - beda dengan sekitarnya. Permasalahan penuaan atau kelompok lanjut usia menjadi salahsatu kelompok yang lebih rentan terhadap masalah ini. Lanjut usia seringkali mendapat tekanan yang cukup besar karena mereka mengalami banyak perubahan dan kehilangan di masa tuanya seperti kehilangan pasangan, anggota keluarga, maupun teman; kehilangan kegiatan yang bermakna serta kehilangan pendapatan karena telah memasuki masa pensiun, penurunan kesehatan, serta tidak lagi bisa mandiri seperti saat muda, juga seringkali terdapat perasaan tidak berarti (Skidmore \& Trackeray, 1994).

Menurut Levin (2000), keberfungsian sosial dapat menjadi variabel prediktor atau variabel yang mempengaruhi atau menjadi sebab perubahan kesehatan, keberfugsian fisik, serta akivitas harian. Sebagai variabel prediktor, penilaian keberfungsian sosial dapat menentukan kecenderungan lansia yang mengalami isolasi sosial atau kekurangan dukungan sosial, menentukan kecukupan tambahan dukungan yang telah diberikan, memahami nilai yang dimiliki lansia tentang kondisi sosialnya, sebagai bagian dari asesmen klinis untuk mengetahui sumber daya sosial yang dimiliki, serta mengetahui faktor resiko dalam penempatan lansia di panti jompo.

Dalam hal ini, penilaian keberfungsian sosial lanjut usia di Panti dilaksanakan sebagai bagian dari asesmen klinis pada lanjut usia, untuk mengetahui sumber daya yang dimiliki oleh lansia serta untuk menentukan kebutuhan layanan bagi lansia dengan berbagai kondisi keberfungsian sosial yang ada di Panti, sehingga tercipta layanan lebih baik bagi lansia di Panti.

Mc.Dowell, et.al dan Froland menjelaskan definisi keberfungsian sosial sebagai berikut, Social Functioning is the dimension of health and wellbeing that reflects how individuals get along with others, how others react to them, how well they perform socially expected roles, and how they interact with social institutions. Berdasarkan definisi tersebut, keberfungsian sosial pada lanjut usia merupakan kemampuan lansia dalam bersosialisasi dan saling memberi respon positif dengan orang lain, mampu melaksanakan peran sosial sesuai status yang disandang, serta 
kemampuan lansia berinteraksi dengan lembaga sosial. Menunjang hal tersebut, Levin (2000) pun membagi 5 (lima) domain utama dalam asesmen dan pengukuran keberfungsian sosial pada lanjut usia yakni Social Support, Social Network, Social Resources, Social Role and Role Functioning, dan Activities.

\section{Dukungan Sosial}

Menurut Antonucci dkk, 'Social support has been defined as the assistance that is provided through older adults' social network (actual support) and the subjective interpretation of contribution made by others'. Berdasarkan definisi tersebut, lanjut usia perlu mendapatkan berbagai jenis bantuan dari jaringan sosial yang mereka miliki. Cohen \& Wills menjelaskan jenis jenis dukungan sosial yang dibutuhkan lansia adalah dukungan emosional, dukungan infomasi, dukungan persahabatan, dukungan instrumental, dan dukungan umum. Heitzmann \& Kaplan meyakini dukungan sosial dapat mempengaruhi hasil kesehatan, jika seseorang memiliki jaringan dukungan sosial yang aktif maka dapat membantu lansia lebih berhasil dalam mengelola kondisi kronis atau kecacatan yang dialami dengan baik. Dukungan emosional pun dapat mempengaruhi pemulihan kapasitas fungsional (Levin, 2000).

Dengan demikian, jenis pertanyaan yang perlu diberikan dalam menilai keberfungsian sosial antara lain; jumlah dukungan sosial yang diterima, serta penilaian tentang kepuasan lansia tentang dukungan sosial yang ia terima. Dalam penilaian dukungan sosial, terdapat pula alat ukur yang dapat digunakan diantaranya Inventory for Socially Supportive Behaviors (ISSB), Interview Schedule for Social Interaction (ISSI), Perceived Social Support - Family and Friend Scale, serta Multidimensional Scale of Perceived Social Support.

\section{Jaringan Sosial}

Jaringan sosial merupakan pihak pihak yang memberikan bantuan, dukungan, maupun pelayanan bagi lanjut usia baik yang bersifat formal maupun nonformal. Menurut Lindsey \& Hughes, jaringan sosial dapat membantu individu mengatasi rasa sakitnya, mencegah isolasi sosial, serta menyediakan sumber daya yang dapat membuat lanjut usia seperti tinggal di rumahnya sendiri. Penilaian jaringan sosial lanjut usia mencakup dua hal yakni besaran jaringan sosial, frekuensi kontak, dan jenis kegiatan yang dilakukan bersama, serta informasi tentang kepuasan lansia atas kontak, kegiatan, dan aktivitas yang dilakukan bersama ters ebut. Asesmen jaringan sosial dapat pula menggunakan alat ukur Lubben's Social Network Scale (LSNS).

\section{Sumber Daya Sosial}

Sumber daya sosial merupakan sumber daya nyata yang tersedia bagi lanjut usia, meliputi keuangan, perumahan, lingkungan tetangga, dan sumber daya komunitas (Kane, 1995). Sumber daya sosial ini sangat mempengaruhi keberfungsian sosial, karena tanpa sumber daya yang kuat, keberfungsian individu dapat terganggu. Pelayanan berbasis institusi seperti panti lanjut usia dapat menjadi salahsatu sumber daya yang dimanfaatkan bagi lanjut usia yang tidak memiliki keluarga atau lansia yang tidak mendapatkan perawatan dalam keluarga (Kroemeke and Gruszczynska, 2016). Sementara itu pengumpulan informasi tentang sumber daya sosial ini juga penting karena dapat membantu pemberi layanan dalam menentukan alternatif yang tersedia dalam mengatasi masalah lanjut usia. Penilaian sumber daya sosial dapoat menggunakan bagian dari skala Older American Resources and Services Multidimentional Functional Assessment Questionnaire (OARS). 


\section{Peran Sosial dan Keberfungsian Peran}

Peran sosial merupakan perilaku individu yang berkesesuaian dengan statusnya dalam sebuah organisasi, kelompok maupun dalam masyarakat. Peranan orang dewasa biasanya tekait dengan pernikahan, orangtua, keluarga, pekerjaan, maupun peran dalam masyarakat. Penilaian peran sosial dan keberfungsian peran seseorang dilakukan dengan mengevaluasi jumlah peran yang disandang serta kepuasan lansia atas pelaksanaan peran tersebut. Hal ini penting untuk dilakukan karena permasalahan kesehatan fisik atau kesehatan mental dapat mempengaruhi pelaksanaan peran dan keberfungsian seseorang. Dalam asesmen ini dapat digunakan pula instrumen The Role Count Index (RCI), sebuah alat ukur yang dikembangkan oleh Cumming \& Henry pada tahun 1961.

\section{Aktivitas Sosial}

Informasi tentang aktivitas sosial digunakan selain untuk mengetahui minat, preferensi, serta tanggung jawab, juga untuk mengetahui gaya hidup yang dijalani oleh lanjut usia. Pengumpulan informasi ini dilakukan sehingga dapat diketahui seberapa penting aktivitas sosial yang dijalani oleh lanjut usia tersebut dapat mempengaruhi hidupnya. Aktivitas sosial individu termasuk didalamnya pekerjaan, aktivitas hiburan, pekerjaan sukarela, keanggotaan dalam kelompok sosial, dan aktivitas menghibur lain yang menyenangkan bagi mereka. Pendapat Levin diatas, diperkuat pula oleh Kane (1987), dimana pendapatnya bahwa keberfungsian sosial bagi lanjut usia memiliki enam aspek yakni Social Relationships, Social Activities, Social Resources and Environtment, Social Support, Caregiver and Caregiver Burden, dan Quality of Life. Pemilihan aspek dari Levin didasarkan pada keempat dari aspek Kane cenderung sama dengan yang telah disebutkan oleh Levin yakni dukungan sosial, jaringan sosial (hubungan sosial), sumber daya sosial, dan aktivitas sosial, hanya saja pada aspek yang disampaikan Levin menambahkan terkait Peran Sosial dan Keberfungsian Sosial Peran. Hal ini penting, karena salahsatu inti dari Keberfungsian Sosial yakni kemampuan menjalankan peran sosial (Siporin, 1975; Achlis, 2011; Garthwait, 2015).

\section{Peran Pekerja Sosial Dalam Pelayanan Panti Usia Lanjut}

Pelayanan Sosial Lanjut Usia diatur dalam Peraturan Menteri Sosial Nomor 19 Tahun 2012 tentang Pedoman Pelayanan Sosial Lanjut Usia, yang diartikan sebagai "Upaya yang ditujukan untuk membantu lanjut usia dalam memulihkan dan mengembangkan fungsi sosialnya". Pelayanan tersebut dapat dilakukan di dalam panti maupun diluar panti. Pelayanan didalam panti dilaksanakan dengan menempatkan lansia dalam pengasramaan di panti untuk memenuhi kebutuhan hidupnya secara lebih layak, jenis layanannya berupa penyediaan tempat tinggal, kebutuhan sehari - hari, pengisian waktu luang, bimbingan sosial, keterampilan, agama, serta pemakaman.

Pelayanan Sosial merupakan sebuah kegiatan yang dilaksanakan oleh pemerintah lokal atau pusat atau organisasi tertentu yang bertujuan untuk membantu individu, keluarga, kelompok, serta masyarakat serta mengatasi permasalahan sosial yang ada di sebuah wilayah. Pelayanan sosial ini disebut juga pelayanan kesejahteraan sosial. Sementara itu menurut Gibelman (2005), pelayanan sosial mencakup seluruh layanan yang bertujuan pada pencegahan, peningkatan, atau penyelesaian masalah kesehatan, kesehatan mental, sosial, atau lingkungan yang memengaruhi individu, keluarga, kelompok tertentu, atau masyarakat. 
Tahap pelayanan yang dilaksanakan berdasarkan tahap pertolongan pekerja sosial, menurut Siporin (1975) terdapat 5 tahap pertolongan pekerja sosial Engangement, Intake, and Contract, Assessment, Planning, Intervntion, serta Evaluation and Termination. Asesmen merupakan salahsatu tahapan pertolongan pekerja sosial yang paling penting, jenis jenis asesmen yang dilakukan pada lanjut usia dalam lingkup panti meliputi kesehatan atau keberfungsian fisik, kemampuan dalam aktivitas kehidupan sehari-hari (ADL), asesmen psikologis emosional, spiritualitas, seksualitas, keamanan lingkungan, dan keberfungsian sosial (Dittrich, 2016). Keberfungsian sosial merupakan salahsatu jenis asesmen yang harus dilakukan oleh pekerja sosial. Dengan dilakukannya asesmen ini akan didapatkan pemahaman tentang kondisi, permasalahan serta kebutuhan klien terkait keberfungsian sosialnya.

Peranan pekerja sosial di Panti Lanjut Usia meliputi; 1) Brokering services. Pada layanan ini pekerja sosial membantu menghubungkan lanjut usia yang memiliki keterbatasan dan kesulitan untuk menghubungkan mereka dengan sistem sumber yang tersedia disekitarnya; 2) Manajemen kasus atau layanan manajemen kasus. Pekerja sosial menyediakan rangkaian layanan pemenuhan kebutuhan lanjut usia; 3) Advokasi. Pekerja sosial diharapkan dapat melakukan advokasi atau pembelaan demi pemenuhan kebutuhan layanan lanjut usia; 4) Konseling individu dan keluarga. Pekerja sosial melakukan konseling individu atau keluarga untuk mengetahui kebutuhan, kekuatan, dan sistem sumber yang ada disekitar lanjut usia; 5) Konseling Kedukaan. Lanjut usia seringkali memerlukan konseling ketika mereka mengalami kehilangan; 6) Pelayanan intervensi krisis. Pekerja sosial memberikan layanan intervensi guna menstabilkan kondisi krisis yang dialami oleh lanjut usia dan keluarga; 7) Pelayanan perlindungan lanjut usia. Pekerja sosial memberikan perlindungan lanjut usia yang rentan atas perlakuan salah; 8) Kelompok terapeutik dan kelompok bantu diri. Peksos memfasilitasi pembentukan kelompok bantu diri dan terapeutik guna penyesuaian diri, dan pembentukan strategi koping penyakit terminal.

Berdasarkan hal tersebut sebenarnya perawatan terbaik lanjut usia adalah pada keluarga dan masyarakat, karena keluarga merupakan tempat yang paling sesuai untuk melayani lanjut usia, selain itu keluarga mempunyai kewajiban moral untuk tetap mengurus orang tuanya (Padmiati dan Diyanayati, 2015). Meskipun begitu, terdapat beberapa kondisi yang membuat tanggung jawab keluarga pada perawatan lansia menurun seperti perubahan struktur keluarga, melemahnya sistem kekerabatan sosial, dan pergerseran peran dalam keluarga (Syamsuddin, Santi, \& Alimuddin, 2018).

Walaupun sistem panti merupakan pilihan terakhir untuk memberikan perawatan bagi lanjut usia, namun banyak lanjut usia yang masuk kategori miskin dan terlantar, yang akhirnya harus masuk panti karena tidak ada keluarga yang mengurus. Hampir seluruh lanjut usia yang tinggal di Panti Pelayanan Sosial Lansia Bojongbata Pemalang merupakan lanjut usia terlantar, mereka tidak memiliki lagi keluarga yang dapat merawatnya. Dalam hal ini panti menjadi salahsatu sumber daya sosial yang tersedia di masyarakat yang dapat diakses untuk lansia terlantar. Dengan demikian, penelitian ini bertujuan untuk mengidentifikasi keberfungsian sosial lanjut usia melalui kelima aspek Levin tersebut, untuk kemudian hasil asesmen dapat pula menunjukkan kebutuhan pelayanan lanjut usia dalam upaya memberikan pelayanan yang lebih baik bagi lanjut usia, serta dapat memberikan kontribusi dalam pengembangan instrumen asesmen keberfungsian sosial lansia di Panti. 


\section{Metode}

Penelitian ini menggunakan pendekatan kualitatif dengan desain studi multi-kasus. Pendekatan kualitatif adalah metode yang digunakan untuk mengeksplorasi dan memahami makna yang oleh sejumlah individu atau sekelompok orang dianggap berasal dari masalah sosial atau kemanusiaan (Creswell, 2014). Sementara desain multi-kasus merupakan bagian dari desain studi kasus tujuan dari desain ini adalah untuk mempelajari secara intensif mengenai unit sosial tertentu, serta menemukan kekhasan, persamaan ataupun perbedaan dari setiap unit tersebut (Yin, 2012). Dengan digunakannya pendekatan dan desain ini, peneliti diharapkan dapat menggali terkait keberfungsian sosial lanjut usia di panti melalui kelima aspeknya serta menemukan persamaan dan perbedaan yang ada terkait kondisi setiap aspek keberfungsian sosial para lanjut usia tersebut.

Penelitian melibatkan 5 (lima) orang informan utama yakni 3 orang lanjut usia potensial meliputi inforrman L, SH, dan W serta 2 lanjut usia non potensial yakni informan SS dan T, pemilihan ini didasarkan pada pengelompokan lansia di Panti. Kelompok lanjut usia potensial masih bisa aktif bersosialisi dengan lingkungan serta mengikuti berbagai kegiatan yang ada di Panti, diindikasikan masih dapagt berfungsi secara sosial. Sementara lanjut usia non potensial, dengan keterbatasan sosialisasi dan aktivitas mereka diindikasikan memiliki masalah keberfungsian sosial. Pemilihan dua kelompok ini diharapkan dapat memenuhi pola replikasi literal dan pola replikasi teoritis yang menjadi kekuatan dari studi multikasus. Pengumpulan data dilakukan dengan wawancara mendalam, observasi, serta kajian pustaka.

Dalam desain studi multi kasus, terdapat beberapa strategi analisis data. Pada penelitian ini, peneliti memilih untuk menggunakan teknik logika penjodohan pola. Pada logika ini, peneliti akan membandingkan pola yang didasarkan atas data temuan lapangan dengan pola yang diprediksikan atau dengan beberapa prediksi alternatif (Yin, 2012). Jika kedua pola ini ada persamaan, hasilnya dapat menguatkan validitas internal studi kasus yang bersangkutan.

\section{Hasil dan Pembahasan}

Panti Pelayanan Sosial Lanjut Usia Bojongbata Pemalang (Panti Kelas A) merupakan unsur pelaksana tugas teknis operasional dari Dinas Sosial Provinsi Jawa Tengah yang mempunyai Tugas Pokok dan Fungsi yang menangani Lanjut Usia Terlantar. Kapasitas Panti Pelayanan Sosial Lanjut Usia Bojongbata Pemalang adalah 100 Penerima Manfaat. Berdasarkan data Per Juni 2020 Jumlah Penerima Manfaat Laki laki 37 orang dan Perempuan 63 orang, mereka adalah lanjut usia yang telah memenuhi persyaratan yakni lanjut usia terlantar dan kondisi ekonomi miskin berumur 60 tahun keatas yang dibuktikan dengan surat keterangan dari Kelurahan / Kecamatan / Dinas Sosial domisili, serta sehat jasmani dan rohani yang dibuktikan dengan surat keterangan dokter.

Pelayanan oleh pihak Panti dilaksanakan dengan program; 1) Pemenuhan Kebutuhan Pokok lanjut usia berupa pemberian tempat tinggal atau pengasramaan, pemberian makanan dan snack harian, perawatan kesehatan, pemberian alat kebersihan diri, dan jaminan keamanan selama tinggal di Panti; 2) Bimbingan fisik dan mental meliputi Olah Raga, Orientasi dan Mobilitas, Agama, Budi pekerti; 3) Bimbingan Sosial meliputi : Bimbingan Activity Daily Living, Bimbingan kelompok, bimbingan kecerdasan, kewiraswastaan; 4) Bimbingan Latihan Ketrampilan meliputi 
Karya tangan, Home Industri serta bimbingan ekstrakurikuler Hadroh Rebana; 5) Resosialisasi; dan 6) Terminasi meliputi Reunifikasi (kembali kepada keluarga) dan Pemakaman.

Ketika lanjut usia masuk ke Panti, ia akan dihadapkan dengan kondisi yang berbeda dengan sebelumnya, seperti bertemu dengan banyak orang baru, perbedaan lingkungan tempat tinggal, perbedaan aktivitas, serta akan adanya keterikatan lanjut usia dengan aturan aturan yang ada di Panti. Selain itu bisa timbul pula perasaan sedih, kecewa, atau merasa tersisihkan karena harus meninggalkan tempat dan lingkungan asalnya. Hal tersebut yang kemudian membutuhkan proses penyesuaian diri bagi lanjut usia dan kemudian dapat mempengaruhi keberfungsian sosialnya selama tinggal di Panti.

Menurut Mc.Dowell, et.al dan Froland dalam Levin (2000), keberfungsian sosial pada lansia merupakan kemampuan lansia dalam bersosialisasi dan saling memberi respon positif dengan orang lain, melaksanakan peran sosial sesuai status yang disandang, serta kemampuan lansia berinteraksi dengan lembaga sosial. Merujuk pada hal tersebut, Levin (2000) membagi 5 (lima) aspek yang digunakan dalam asesmen dan pengukuran keberfungsian sosial pada lanjut usia yakni Sumber Daya Sosial, Aktivitas Sosial, Jaringan Sosial, Dukungan Sosial, Aktivitas Sosial, dan Peran Sosial serta keberfungsian peran. Kelima aspek tersebut diatas saling berhubungan dan mempengaruhi satu sama lain.

Asesmen keberfungsian sosial yang dilakukan pada 5 (lima) orang informan menunjukan bahwa setiap aspek Levin penting untuk dinilai dan merupakan bagian bagian yang sulit untuk dipisahkan. Secara ringkas hasil asesmen menunjukkan sebagai berikut :

\section{Informan L}

Informan L yang berusia 61 tahun memiliki kondisi fisik yang masih bugar. Selain itu karena didukung dengan kemauan dari dalam dirinya untuk mengisi waktu luang dengan hal yang bermanfaat, menjadikan informan L cukup aktif dalam berbagai kegiatan bimbingan maupun kegiatan lainnya di Panti. Pemanfaatan informan akan adanya sistem sumber yang tersedia atau dalam hal ini panti, tercermin dalam keterlibatannya dalam setiap bimbingan yang ada di Panti, informan memahami akan kewajibannya dan hak nya sebagai penerima manfaat (L, wawancara personal, 22 Juni 2020).

Keterlibatan lansia dalam berbagai aktvitas sosial yang ada serta pemanfaatan pada sumber daya sosial yang tersedia, semakin memperluas jaringan sosialnya. Informan memiliki hubungan pertemanan yang baik dan mengenal banyak orang. Kekuatan jaringan sosial lanjut usia ini menjadikan ia mendapat dukungan sosial yang besar dari sekitarnya, tak hanya dari lingkungan panti melainkan juga dari keluarganya. Dengan adanya dukungan sosial tersebut, informan menjadi lebih percaya diri dalam bergaul serta mendorong informan untuk menjalankan peran sosialnya dengan baik sebagai orang yang dituakan oleh keluarga, penerima manfaat, serta anggota kelompok pengajian.

\section{Informan SH}

Menurunnya kesehatan informan SH menjadikan aktivitas sosialnya berkurang, namun ia tetap dapat berinteraksi dengan teman walaupun ia tidak memiliki teman dekat. Meskipun begitu informan dapat sumber daya sosial dengan baik dengan mengikuti bimbingan, inisiatif berkonsultasi pada pekerja sosial, juga meminta obat jika ada keluhan. Keterlibatan tersebut semakin menguatkan jaringan sosialnya informan. Kekuatan jaringan sosial lanjut usia ini pun 
membuatnya bisa mendapat dukungan sosial yang besar dari lingkungan sekitar. Informan mendapatkan dukungan emosional, dukungan informasional, serta dukungan instrumental.

Dengan adanya hal hal tersebut diatas, informan dapat menjalankan peran sosialnya dengan baik sebagai orang yang dituakan oleh keluarga serta penerima manfaat yang mendapatkan kesan baik di Panti. Ia bertanggung jawab akan tugasnya sejak awal membantu kawan - kawan, walau kesehatannya menurun. Ia pun selalu berusaha untuk tidak merepotkan keluarganya. (SH, wawancara personal, 19 Juni 2020).

\section{Informan W}

Informan W hanya memanfaatkan pengasramaan dan pemenuhan kebutuhan dasar, hal ini karena kekurangpahaman informan akan program pelayanan di Panti dan segan untuk menyampaikan keluhan (W, wawancara personal, 17 Juni 2020). Kurangnya aktivitas yang dilakukan informan dan minimnya pemanfaatan pada sumber daya menyebabkan kurang kuatnya jaringan sosial informan dengan teman teman dan petugas di Panti.

Kurang kuatnya jaringan sosial informan menyebabkan berkurangnya dukungan sosial yang ia terima. Informan mendapat dukungan emosional, dukungan informasi, dukungan instrumental, serta dukungan companionship dari panti. Kurang baiknya berbagai aspek tersebut diatas dapat menjadikan informan mengalami kesulitan dalam menjalankan peran sosialnya.

\section{Informan SS}

Kondisi fisik informan SS mengalami kelumpuhan sebelah kanan sehingga menghambat mobilitasnya dan membatasinya melakukan aktivitas sosial. Meskipun begitu ia memiliki kemampuan komunikasi yang baik masih sehingga ia tetap dapat berhubungan sosial dengan orang lain walau hanya berupa percakapan ringan. Informan pun cukup dapat memaksimalkan pemanfaatan sistem sumber daya sosial yang ada dalam hal ini panti. Walaupun tidak bisa rutin mengikuti berbagai bimbingan yang ada di Panti informan tetap turut mendengarkan pengajian dari asrama, ia pun memiliki inisiatif untuk meminta pemeriksaan kesehatan ketika merasa sakit (SS, wawancara personal, 16 Juni 2020).

Aktivitas sosial yang tetap dilaksanakan dan pemanfaatan terhadap sumber daya sosial, menjadikan informan memiliki jaringan sosial yang cukup baik dengan keluarganya, teman dan pegawai panti. Keberadaan jaringan sosial ini yang menjadikan lansia mendapatkan dukungan sosial yang baik dari sekitarnya berupa dukungan emosional, dukungan infomasional, dukungan companionship, serta dukungan instrumental. Adanya dukungan sosial tersebut menjadi tambahan kekuatan bagi informan untuk tetap melaksanakan peran sosial yang ada pada dirinya yakni sebagai penerima manfaat di Panti serta nenek dan ibu bagi cucu dan anaknya.

\section{Informan $T$}

Kondisi stroke menjadikan aktivitas informan $\mathrm{T}$ sangat terbatas, ia pun hanya dapat menggunakan panti sebagai sumber daya untuk mendapatkan pemenuhan kebutuhan dasar. Hal tersebut menjadikan jaringan sosial informan kurang kuat. Jaringan sosial yang cukup kuat hanyalah pihak panti dalam hal ini petugas dan pengasuh panti, itupun sifatnya satu arah menuju penerima manfaat.

Lemahnya jaringan sosial informan menyebabkan kurangnya dukungan sosial yang diterima. Informan hanya menerima dukungan fisik, dan dukungan emosional dari pihak panti. Kurangnya dukungan dari pihak lain yang diterima informan serta hilangnya dukungan utama 
yang informan dapatkan saat meninggalnya suami pun sangat mempengaruhi informan untuk menjalankan peran sosialnya.

Dalam penelitian ini dilakukan pula analisis setiap aspek yang bertujuan untuk mengetahui hubungan antar aspek serta kekuatan dan kebutuhan layanan dalam meningkatkan setiap aspek untuk para lanjut usia.

\section{Sumber Daya Sosial}

Lanjut usia kurang mampu dan terlantar, mereka tidak lagi memiliki pendapatan, tempat tinggal ataupun kerabat yang dapat mengasuhnya. Pelayanan berbasis institusi atau Panti merupakan salahsatu sumber daya yang tersedia bagi lanjut usia yang dapat menjadi jejaring dan memberikan dukungan sosial bagi lanjut usia. (Kroemeke and Gruszczynska, 2016). Selain pelayanan dan program yang ada di Panti, informan pun dapat memanfaatkan jaringan - jaringan terkait dengan panti seperti puskesmas, rumah sakit, dinas kependudukan dan catatan sipil, dinas sosial, dan lainnya.

Kelima informan memanfaatkan pelayanaan utama yang sama yang ada di panti berupa pengasramaan, pemenuhan kebutuhan dasar berupa permakanan, pakaian, alat kebersihan diri, serta pelayanan kesehatan rutin yang dilakukan oleh perawat dan dokter. Yang membedakan setiap kasus adalah ada atau tidaknya inisiatif untuk dapat lebih memaksimalkan pemanfaatan layanan di Panti. Informan SH, L, dan SS mereka lebih memiliki inisiatif untuk meminta atau bertanya pada petugas panti, seperti meminta obat dan menyampaikan keluhan pada perawat ketika ada sakit yang dirasa (tidak hanya menunggu pemeriksaan), menceritakan atau berkonsultasi pada pekerja sosial dan pengasuh ketika ada masalah yang dihadapi.

Dengan adanya inisiatif atau upaya mandiri dari penerima manfaat untuk menjangkau layanan di Panti, dapat meningkatkan pula pelayanan yang diberikan pada lanjut usia. Saat ini jumlah tenaga kesehatan dan pekerja sosial di panti masih terbatas dan tidak berimbang dengan jumlah penerima manfaat sehingga cukup sulit untuk secara intens mengetahui perkembangan harian para penerima manfaat. Jumlah pekerja sosial di Panti adalah 4 orang, sementara tenaga perawat 3 orang sementara jumlah penerima manfaat adalah 100 orang dengan kondisi yang beragam, sehingga inisiatif dari penerima manfaat juga dirasa sangat perlu. Meskipun begitu perlu pula diawali dengan edukasi pada lanjut usia terkait gejala penyakit yang mereka alami.

Sumber daya sosial lain yang dimiliki lansia adalah adanya keluarga dan hubungan kekerabatan, yang dimiliki oleh informan L, SS, SH, dan W. Keberadaan keluarga dan hubungan kekerabatan yang mereka miliki dapat menjadikan menentukan jumlah pihak - pihak yang masih memiliki kontak dengan informan walaupun saat ini tinggal di Panti. Ketersediaan dan pemanfaata sistem sumber dapat membantu lansia dalam mengaatasi permasalahan yang mereka hadapi seperti gangguan kesehatan, masalah dengan sesama penerima manfaat, mengatasi stres, kebutuhan akan informasi, dan lainnya.

Kebutuhan layanan lansia berkaitan dengan sumber daya sosial adalah kebutuhan informasi dan edukasi terkait keberadaan dan cara mengaskses setiap sistem sumber yang tersedia di panti maupun masyarakat. Begitu pula terkait dengan keluarga, panti diharapkan dapat memberi kesempatan bagi lansia untuk tetap berinteraksi dengan keluarga serta membantu mediasi jika ada lansia yang membutuhkan kontak dengan keluarga tapi mengalami kesulitan. Hal ini berlaku bagi seluruh lansia, baik potensial maupun nonpotensial.

\section{Aktivitas Sosial}


Sementara itu terkait aktivitas sosial lanjut usia yang tinggal di Panti meliputi seluruh kegiatan yang dilakukan oleh lanjut usia sehari - hari, kegiatan waktu luang, maupun keterlibatannya di dalam kelompok - kelompok yang ada di Panti. Graney and Graney pun menyertakan berbincang dengan keluarga dan teman sebagai aktivitas bagi individu yang tidak lagi mampu melaksanakan aktivitas fisik dan aktivitas sosial lainnya (Levin, 2000). Hal tersebut menegaskan bahwa penurunan dan perubahan kondisi fisik lanjut usia seringkali menurunkan aktivitas sosial mereka.

Informan SH, L, dan W memiliki kondisi fisik yang masih cukup sehat, mereka tidak mengalami hambatan apapun dalam mobilitas serta Activity Daily Living. Meskipun begitu, informan SH dan SS lebih banyak memiliki aktivitas sosial dibanding informan W, karena informan W tidak mau lagi mengikuti kegiatan kegiatan yang ada di Panti dengan alasan capek atau malas (W, wawancara personal, 17 Juni 2020). Hal ini dapat terjadi selain karena usia informan $\mathrm{W}$ yang sudah sangat tua dan kesehatannya menurun, juga karena informan $\mathrm{W}$ kurang memiliki motivasi untuk mengikuti kegiatan bimbingan yang ada.

Sementara itu untuk informan $\mathrm{T}$ dan SS, dimana keduanya mengalami persamaan hambatan mobilitas karena pasca stroke yang mereka derita, terdapat perbedaan aktivitas sosial. Informan SS walaupun tidak bisa melakukan aktivitas di luar ruangan karena kelumpuhan anggota gerak kanananya, ia masih sering beinteraksi serta berbincang dengan teman temannya. Hal ini menyebabkan informan SS tampak ceria dan bersemangat setiap harinya. Kondisi ini cukup berlawanan dengan kondisi informan T. Meskipun informan T mengalami gangguan motorik yang mengganggu pula kemampuan bicaranya, namun ia sebenarnya masih mampu jika dilatih secara rutin. Menurut pekerja sosial terkadang ia masih dapat merespon dengan kata kata sederhana ketika ditanya oleh petugas (PS, wawancara personal, 24 Juni 2020).

Kurangnya aktivitas lanjut usia juga dapat disebabkan oleh masih kurangnya variasi kegiatan yang ada di Panti, lokasi yang terlalu jauh untuk dijangkau oleh lansia, serta kegiatan yang belum memenuhi minat dam hobi mereka. Kegiatan yang ada saat ini lebih banyak melibatkan lanjut usia potensial, sementara kegiatan untuk lansia non potensial masih minim. Sementara lanjut usia potensial pun seringkali mengeluh capek karena kegiatan di ruangan serbaguna meski ruangan tersebut hanya berjarak 500 meter dari asrama dan lokasi tersebut sudah dipilih yang paling strategis agar mudah dijangkau bagi lansia dari semua asrama.

Kebutuhan layanan lansia terkait aspek aktivitas sosial adalah kebutuhan akan adanya aktivitas yang dapat melibatkan seluruh lansia baik produktif maupun nonproduktif dengan tempat yang mudah dijangkau, misalkan di asrama masing - masing. Selain itu, perlu dilakukan analisis yang lebih mendalam untuk setiap individu terkait kemampuan untuk mengikuti aktivitas, kesulitan yang dihadapi, serta keterbatasannya.

\section{Jaringan Sosial}

Kemampuan memanfaatkan sumber daya sosial yang tersedia serta melaksanakan aktivitas sosial sesuai kemampuan, sangatlah mempengaruhi jaringan sosial lanjut usia. Semakin banyak informan mengakses sumber daya yang tersedia serta memiliki aktivitas sosial yang cukup dapat memperkuat jaringan sosial lanjut usia. Hal ini karena informan akan dapat lebih bertemu dan berinteraksi dengan banyak orang, sehingga memungkinkan membentuk jaringan yang lebih luas. 
Pada kasus informan SH, L, dan SS yang dapat memanfaatkan sistem sumber dengan lebih baik dan memiliki aktivitas sosial yang cukup daripada informan $\mathrm{W}$ dan $\mathrm{T}$, mereka bertiga memiliki jaringan yang baik dengan keluarga, teman, maupun lingkungan dan petugas panti. Walaupun komunikasi dengan keluarga tidak menentu intensitas dan jangka waktunya, tapi mereka saling memahami dan mengerti serta tidak menuntut banyak hal dari keluarganya.

Meskipun begitu, informan SH memiliki jaringan yang cukup lemah dengan teman, ia tidak memiliki teman yang dianggap dekat atau bisa dipercaya di Panti. ( $\mathrm{SH}$, wawancara personal, 19 Juni 2020). Hal ini dapat dipengaruhi karena kepribadian informan yang lebih tertutup. Berkesesuaian dengan teori C.G. Jung dalam Jamil (2015) bahwa lansia dengan tipe kepribadian ekstrovert cenderung lebih mudah menjalin pertemanan, meminta pertolongan dari orang lain, aktif di kelompok atau masyarakat, serta lebih berani tampil di depan orang banyak. Dan ini berkebalikan dengan informan $\mathrm{SH}$.

Sementara informan $\mathrm{W}$ dan $\mathrm{T}$ yang lebih tertutup dan jarang berinteraksi dengan orang lain, memiliki jaringan sosial yang lebih sedikit atau lebih lemah, meskipun kondisinya cenderung sama yakni tidak memiliki keluarga inti. Selain itu hal ini dapat pula dipengaruhi juga dengan kemampuan bersosialisasi informan, dimana kemampuan tersebut dapat membantu individu dalam mengembangkan hubungan dengan orang lain (Erozkan, 2013). Informan SH, L, dan SS lebih aktif berkomunikasi, mampu menyesuaikan diri, ramah dan mudah bergaul dengan orang lain dibandingkan dengan informan $\mathrm{W}$ dan $\mathrm{T}$. Hal ini dapat pula menyebabkan jaringan sosial mereka, karena orang yang memiliki kemampuan sosial dan bersosialisasi yang baik lebih mudah akrab dan dapat menjalin hubungan positif dengan pihak lain.

Menurut Lindsey dan Hughes dalam Levin (2000), keberadaan jaringan sosial sangatlah penting bagi lansia, karena dapat membantu individu mengatasi penyakitnya, mencegah isolasi sosial, serta menyediakan dukungan yang dapat membantu lansia mengatasi masalahnya. Hal ini tampak pada informan L, SH, SS yang tampak lebih semangat dalam menjalani kesehariannya.

Kebutuhan layanan pada aspek jaringan sosial adalah terkait dengan menjaga kualitas hubungan dari setiap jaringan yang masih ada pada lansia, hal ini dapat dilaksanakan dengan melaksanakan kegiatan bimbingan sosial atau dinamika kelompok yang dapat lebih mendekatkan lansia dengan teman - teman, maupun membantu lansia untuk berkomunikasi dengan keluarganya.

\section{Dukungan Sosial}

Tidak semua jaringan sosial dapat menyediakan atau memberi dukungan bagi inividu, namun semakin kuat jaringan sosial yang dimiliki individu maka akan semakin besar pula peluang saling memberikan dukungan. Baik berupa dukungan emosional, informasi, companionship, dan dukungan instrumental merupakan bentuk dukungan yang dibutuhkan oleh lanjut usia tetap bersemangat di sisa hidupnya.

Seluruh informan mendapat dukungan yang sama dari pihak panti berupa dukungan emosional, dukungan informasi, dukungan companionship, dan dukungan instrumental. Yang membedakan adalah informan $\mathrm{T}$ dan SS, mendapat dukungan fisik lebih banyak karena mereka memiliki keterbatasan mobilitas dan ADL seperti bantuan untuk mandi, berpakaian, kebersihan, makan, serta aktivitas yang melibatkan fisik lainnya. Berdasarkan hal ini, dukungan sosial dapat diberikan lebih besar berdasarkan tingkat kebutuhan individu. 
Informan SS, L, SH, dan W masih mendapat dukungan dari keluarga meskipun bentuk dan intensitasnya berbeda beda. Informan SS seringkali izin pulang atau dijemput untuk mengunjungi rumah keluarganya di luar kota, selain itu komunikasi lebih banyak dilakukan lewat telepon. Begitu pula pada informan SS dan SH, keluarga mereka cukup sering menghubungi melalui telepon walau hanya sekedar menanyakan kabar atau bercerita tentang kehidupan mereka. Sementara informan W karena asal tempat tinggalnya dekat, ia sering izin pulang mengunjungi keluarga. (W, wawancara personal, 17 Juni 2020).

Berdasarkan kasus individual informan, perbedaan dukungan dari keluarga tersebut dapat disebabkan karena hubungan kekerabatan antar anggota keluarga, kondisi ekonomi, serta kesibukan keluarga. Masalah hubungan kekerabatan keluarga dapat tampak kepada kasus informan $\mathrm{W}$ dimana ia jarang pernah mendapat kunjungan meskipun tempat asalnya dekat dengan panti dan hal ini berbeda dengan informan $L$ yang sangat akrab dengan keluarganya. (L, wawancara personal, 22 Juni 2020). Sementara itu masalah ekonomi terdapat pada kasus informan SS dimana anaknya jarang mengunjungi dan menelepon karena tidak memiliki biaya. Sedangkan masalah kesibukan keluarga terdapat pada kasus informan SH. (SS, wawancara personal, 22 Juni 2020).

Berbeda dengan keempat kasus lainnya, informan $\mathrm{T}$ saat ini hanya mendapatkan dukungan sosial dari panti dan petugasnya. Informan baru saja kehilangan sumber dukungan sosial utamanya yaitu suaminya, dan hal itu cukup membuat perubahan yang signifikan pada diri informan. Semenjak suaminya turut tinggal di Panti, kondisi informan lebih membaik, namun kembali menurun ketika suaminya meninggal dunia.

Kebutuhan layanan dalam aspek dukungan sosial adalah peningkatkan kapasitas SDM panti sehingga dapat memberikan dukungan yang cukup bagi seluruh lanjut usia. Seluruh SDM panti diharapkan dapat memahami perkembangan lanjut usia serta lebih peka pada kondisi lanjut usia.

\section{Peran Sosial dan Keberfungsian Sosial Peran}

Aspek terakhir dari keberfungsian sosial adalah peran sosial dan keberfungsian peran. Keberfungsian peran merupakan inti dari keberfungsian sosial, dimana individu dapat menjalankkan peran sesuai dengan status yang disandang seperti yang diharapkan oleh masyarakat.

Setiap informan sebagai pengguna layanan di panti memiliki peran sebagai penerima manfaat. Bentuk pelaksanaan peran yang ditunjukkan oleh informan sebagai penerima manfaat ditunjukan dengan pemahaman akan hak dan kewajiban, mengikuti setiap kegiatan panti, turut menjaga kebersihan dan keindahan panti, saling membantu sesama penerima manfaat, menghormati sesama penerima manfaat dan petugas panti, serta menjaga ketentraman di lingkungan panti.

Peran lain yang dimiliki lansia adalah sebagai orangatua atau orang yang dituakan di keluarganya. Hal ini berlaku pada informan L, SH, dan SS dimana mereka telah menjalankan peran tersebut meliputi menunjukan kasih sayang pada cucu atau keluarga, menjadi orang yang bijaksana, serta bersedia dimintai dan menyampaikan pendapat. Sementara itu informan W memiliki peran sebagai seorang suami, perlu diberi pemahaman juga untuk lebih memperhatikan dan peduli pada istrinya. Perbedaan pelaksanaan peran sosial individu dapat dipengaruhi oleh pengetahuan yang dimiliki informan, kepuasan terhadap peran yang disandang, serta tuntutan 
dari lingkungan lansia. Kebutuhan layanan pada aspek ini adalah tentang pemberian pemahaman lansia tentang hak dan kewajibannya sebagai penerima manfaat, serta menyediakan media untuk dapat berkonsultasi terkait kesulitan dalam menjalankan peran sosial.

Berdasarkan seluruh temuan di lapangan baik analisa per kasus maupun analisa per aspek, dengan studi multikasus ini telah dilakukan teknik penjodohan pola kemudian ditemukan kesamaan pola pada 5 (lima) kasus informan yakni bahwa lansia yang dapat memanfaatkan sumber daya sosial dengan baik serta memiliki kecukupan aktivitas sosial, maka ia akan memiliki jaringan sosial yang lebih luas dan lebih kuat. Kemudian jaringan sosial tersebut dapat memberi dukungan sosial yang dibutuhkan lanjut usia, yang selanjutnya dapat meningkatkan kemampuan dan membantu lanjut usia dalam melaksanakan peran sosialnya dengan baik. Kondisi maksimal pada setiap aspek ini lah yang kemudian menjadi lansia dapat berfungsi secara sosial. Hal ini berkesesuaian dengan pola yang diprediksikan berdasarkan teori dari Levin.

\section{Kesimpulan}

Asesmen keberfungsian sosial sangatlah penting untuk dilakukan karena dapat mengetahui kondisi, permasalahan, serta kebutuhan layanan lanjut usia agar dapat lebih berfungsi secara sosial. Kecukupan setiap aspek dapat membantu lanjut usia dalam mengatasi dan proses pemulihan bagi penyakitnya, meminimalisir stres, serta mengurangi kemungkinan isolasi sosial, serta menumbuhkan perasaan masih berguna pada lansia.

Berdasarkan penelitian yang telah dilaksanakan, didapat simpulan bahwa kelima aspek keberfungsian sosial yang diutarakan Levin, sumber daya sosial yang dimanfaatkan lansia adalah panti beserta seluruh unsur didalamnya seperti program dan pelayanan, pegawai panti, maupun jaringan terkait panti (fasilitas kesehatan, dinas sosial, dinas kependudukan, dll) serta keluarga bagi yang masih memiliki. Kebutuhan layanannya adalah terkait informasi dan edukasi pemanfaatan sumber daya sosial serta bantuan untuk tetap terhubung dengan keluarga. Lebih jauh, aktivitas lansia di panti terkait dengan bimbingan - bimbingan yang tersedia diantaranya bimbingan fisik, bimbingan sosial, bimbingan keterampilan, bimbingan spiritual. Selain itu terdapat pula aktivitas keagamaan yakni pengajian rutin, serta percakapan sosial yang terjadi antara lansia dengan orang lain. Kebutuhan layanannya adalah variasi kegiatan serta adanya kegiatan yang dapat merangkul seluruh penerima manfaat baik potensial maupun nonpotensial.

Jaringan sosial lansia yakni keluarga, teman, pegawai panti, fasilitas kesehatan, kelompok bimbingan yang diikuti. Sementara kebutuhan layanannya terkait fasilitasi menjaga kualitas jaringan yang ada serta kegiatan kegiatan yang dapat menjaga kekompakan antar penerima manfaat. Dukungan - dukungan yang diterima penerima manfaat yakni dukungan emosional, infomasi, companionship, serta dukungan instrumental, sementara sumber pemberi dukungannya ada yang berasal dari keluarga, teman, maupun dari petugas panti. Kebutuhan layanannya adalah peningkatan SDM Panti dalam memberikan dukungan bagi lansia.

Seluruh informan memiliki peranan sebagai penerima manfaat, selain itu masih ada yang memiliki peran sebagai suami, orang yang dituakan, serta sebagai teman. Kebutuhan layanan lansia terkait dengan pemberian informasi tentang hak dan kewajiban penerima manfaat serta media untuk menyampaikan setiap hambatan dan kesulitan yang dialami.

Dengan dilaksanakan penelitian ini, didapat pola hubungan antar aspek Levin di lapangan yang berkesesuaian dengan pola yang diprediksi, bahwa lansia yang dapat 
memanfaatkan sumber daya sosial dengan baik serta memiliki kecukupan aktivitas sosial, akan memiliki jaringan sosial yang lebih luas dan lebih kuat. Kemudian jaringan sosial tersebut dapat memberi dukungan sosial yang dibutuhkan lanjut usia, yang selanjutnya dapat meningkatkan kemampuan dan membantu lanjut usia dalam melaksanakan peran sosialnya dengan baik. Hal ini yang keemudian dapat mewujudkan keberfungsian sosial lanjut usia menjadi lebih baik

Terdapat faktor - faktor lain yang turut mempengaruhi perbedaan keberfungsian sosial lanjut usia diantaranya perbedaan individual lanjut usia (latar belakang penerima manfaat, kondisi fisik kondisi psikologis emosional, kondisi ekonomi, kemampuan intelektual, kondisi spiritual), inisiatif penerima manfaat, motivasi, tipe kepribadian, kemampuan sosialisasi, tingkat kebutuhan individu, hubungan kekerabatan dengan anggota keluarga, kemampuan keluarga, dan kondisi ekonomi keluarga.

Implikasi dari penelitian ini adalah dapat menyumbangkan satu konsep dalam tahapan pekerjaan sosial dengan lansia terkait asesmen keberfungsian sosial melalui aspek aspek keberfungsian sosial menurut Levin. Konsep ini dapat terus diuji dan dikembangkan dengan kajian lapangan lebih lanjut. Keterbatasan penelitian ini adalah masih kurangnya variasi individual dari lanjut usia yang menjadi informan sehingga masih kurang menunjukan perbedaan antar kelompok lansia. Pada penelitian selanjutnya, diharapkan dapat dibuat dan diujicobakan instrumen baku yang dapat mengukur keberfungsian sosial baik secara kuantitatif maupun kualitatif pada populasi lansia lebih besar besar baik yang tinggal di panti maupun di masyarakat.

\section{Referensi}

Achlis (2011). Praktek Pekerjaan Sosial 1. Bandung : Koperasi STKS Bandung.

Aroogh, M.C \& Shahboulaghi (2020). Social Participation of Older Adults : A Concept Analysis. Int J. Community Based Nurs Wifery, Vol 08 (1). Doi : https://dx.doi.org/10.30476 \%2FIJCBNM.2019.82222.1055

Ashford, J.B. \& LeCroy, C.W. (2018). Human Behavior in the Social Environment : A Multidimentional Perspective, Sixth Edition. USA : Cengage Learning.

Azizah, R., \& Hartanti, R. D. (2016). Hubungan Antara Tingkat Stress Dengan Kualitas Hidup Lansia Hipertensi di Wilayah Kerja Puskesmas Wonopringgo Pekalongan.

Bahramnezhad, F. Chalik, R., et.al (2017). The Social Network Among The Elderly and its Relationship with Quality of Life. Electron Physcian 9 (05). Doi : 10.19082/4306

Chen, Y. Hicks, A. While, A.E. (2014). Loneliness and Social Support of Oder People in China : a Systematix Literatur Review. Health and Social Care in Community. Retrieved form : https://onlinelibrary.wiley.com/doi/pdf/10.1111/hsc.12051

Creswell, J.W. (2014). Research Design, Qualitative Quantitative and Mixed Methods Approach, Fourth Edition. California : SAGE Pub Inc.

Cumming, E., \& Henry, W.E. (1961). Growing Old : The Process of Disengangement. New York : Basic Books.

Dittrich, K.M. \& Lubben (2016). Comprehensive Biopsychosocial Assesments : The Foundation of Social Work Practice with Older Adults. In Kaplan, D.B. \& Berkman, B. (Ed.). The Oxford Handbook of Social Work in Health and Aging. (pp. 9 - 17). New York : Oxford University Press. 
Dubois, B. \& Milley, K.K. (2011). Social Work : An Empowering Profession. United State: Pearson.

Erozkan, A. (2013). The Effect of Communication Skills and Interpersonal Problem Solving Skills on Social Self-Efficacy. Educational Science: Theory and Practice, 13 (2), p. 739 745. Retrieved from : https:// files.eric.ed.gov/fulltext/EJ1017303.pdf

Garthwait, C. (2015). Social Work Practicum : A Guide and Workbook for Student (7th Edition). United State : Pearson.

Gibelman, M. (2005). What Social Workers Do. (2nd Edition). Washington, DC: NASW Press.

Graham, C., Arthur,A., and Howard, R. (2010). The Social Functioning of Older Adults with Schizophrenia. Aging \& Mental Health, Vol. 6 No. 2, DOI : $10.1080 / 13607860220126772$

Graney, M.J. \& Graney, E.E. (1974). Communication Activity Subtitutions in Aging. Journal of Communication. 24 (4), 88-96.

Jariatun, H. (2015). Problem keberfungsian sosial lansia di Panti Wreda Budhi Darma

Yogyakarta. Skripsi. Fakultas Dakwah dan Komunikasi UIN Sunan Kalijaga Yogkayarta.

Jamil, M. (2015). Kepuasan Interaksi Sosial Lansia dengan Tipe Kepribadian. Jurnal Keperawatan, 3 (2), $\quad 171 \quad-182 . \quad$ Retrieved from http:/ / ejournal.umm.ac.id/index.php/keperawatan/article/ view/ 2594/3239

Kane, R.A. (1987). Assessing Social Function in the Elderly. Clinics in Geriatric Medicine, Vol. 3, Issue 1. DOI : 10.1016/S0749-0690(18)30828-0

Kemenkes RI. (2016). Situasi Lanjut Usia di Indonesia (29 Mei 201). Retrieved from https://www.kemkes.go.id/resources/download/pusdatin/infodatin/infodatin lansia 2016.pdf

Kroemeke, A. and Gruszczynska, E. (2016). Well-Being and Institutional Care in Older Adults: Cross-Sectional and Time Effects of Provided and Received Support. PLoS One Journal. Vol 2011, No.8. Doi : 10.1371/journal.pone.0161328

Levin, C. (2000). Social Functioning. In Kane, R.L \& Kane, R.A. (Ed.). Assessing Older Persons : Measures, Meaning, and Practical Conditions. (pp. 170-199). New York : Oxford University Press Inc.

Meesters, P., D., Stek, M., L., Comijs, H., C., Haan, Ld., Patterson, T., L., Eikelenboom, P., \& Beekman, A., T., F. (2010). Social functioning among older community-dwelling patients with schizophrenia: A Review. The American Journal Geriactric Psychiatry, 18 (10) 862-878.

Muthia, G., Krisnani, H., \& Meilani, L. (2016). Peran pekerja sosial dalam meningkatan keberfungsian sosial lansia di PSTW Budi Darma Bekasi. Prosiding KS. Riset \& PKM (3) 292-428. Retrived from http://jurnal.unpad.ac.id/prosiding/ article/view/13776/6579.

Nailufar, N. N. (2019, July 5). Hanya 13,2 Persen Lansia di Indonesia yang Sehat. Kompas.Com. Retrieved from https://sains.kompas.com/read/2019/07/05/120500723/hanya-13-2persen-lansia-di-indonesia-yang-sehat

Pivorene, J. (2008). Changing roles of elders in the family. Social Work Research Journal, 07 (01), Retrieved from : https://www3.mruni.eu/ojs/social-work/article/view/1937/1753 
Seftiani, S. (2018, September 23). Menelaah Program Lansia di Indonesia. LIPI. Retrieved from https://kependudukan.lipi.go.id/en/population-study/publich-health/532-menelaahprogram-lansia-di-indonesia

Siporin, M. (1975). Introduction to Social Work Practice. New York : Mac Milan Publishing.

Skidmore, R.A. \& Trackeray, M.G. (1994). Introduction to Social Work 6th Ed. Englewood Cliffs, N.J : Prentice Hall. Retrieved from : https://archive.org/details/ introductiontoso00skidrich/page/n1

Syamsuddin. (2018). Peningkatan Keberfungsian Sosial Lanjut Usia melalui Program Pelatihan Kembali. Sosio Informa, 4 (2), 437 - 447. Retrieved from : https://doi.org/10.33007/inf.v4i2.1518

Syamsuddin, Santi, K. E., \& Alimuddin, L. (2018). Keberfungsian Sosial Lanjut Usia di Panti Sosial Tresna Werdha Minaula di Kota Kendari. Sosio Konsepsia, 7(3), 205-220. Retrieved from https://ejournal.kemsos.go.id/index.php/SosioKonsepsia/article/view/1449

Wicaksono, K. A. (2017). Pemerintah Identifikasi 3 Masalah Lansia - Ekonomi Bisnis.com. Ekonomi Bisnis. Retrieved from https://ekonomi.bisnis.com/read/20170507/12/651511/pemerintah-identifikasi-3masalah-lansia

Yin, R.K. (2012). Studi Kasus : Desain dan Metode. Jakarta : PT. Raja Grafindo Persada.

\section{Wawancara}

L. Pemalang. 19 Juni 2020.

L. Pemalang. 22 Juni 2020.

Pekerja Sosial. Pemalang. 24 Juni 2020.

SH. Pemalang. 16 Juni 2020.

SH. P emalang. 19 Juni 2020.

SS. Pemalang. 20 Juni 2020.

SS. Pemalang. 22 Juni 2020.

T. Pemalang. 23 Juni 2020.

T. Pemalang, 24 Juni, 2020.

W. Pemalang. 16 Juni 2020.

W. Pemalang. 17 Juni 2020. 